\title{
Climate Change and Finance in Africa: Some Theoretical and Practical Justifications
}

\author{
Oluseun Paseda ${ }^{1}$, Joseph Owolabi ${ }^{2}$, Ogochukwu Okanya ${ }^{3 *}$ \\ 1. Department of Banking and Finance, School of Economics, University of Ibadan, Nigeria, \\ seunpash@yahoo.com \\ 2. Rubicola Consulting and Deloitte, Australia and Asia Pacific, opeowo@gmail.com \\ 3. Department of Banking and Finance, Institute of Management and Technology, Enugu, Nigeria. \\ ogeez_1@yahoo.com \\ * E-mail of the corresponding author: ogeez_1@yahoo.com, ookanya@imt.edu.ng
}

\begin{abstract}
Global warming evidence is worrisome, and its impact has spread across all continents of the world. Unfortunately, many countries are not paying sufficient attention to environmental damages resulting from climate change. Commitments to emissions reductions are also not being honored by countries. This exploratory paper seeks to justify the need for African countries to pursue clear-cut climate mitigation and adaptation strategies and the necessity of integration across multiple disciplines and embraced by both public and private sectors. Climate change is a source of financial risk; it threatens the stability of the financial system through systemic risk factors, produces negative externalities, and creates moral hazard. Innovative debt and equity instruments for funding climate-compatible urban infrastructure are discussed and recommendations made for assessing climate projects.
\end{abstract}

Keywords: Climate Change, Finance, Corporate Finance

JEL: G11, G18, Q54

DOI: $10.7176 /$ RJFA/11-16-18

Publication date:August 31 st 2020

"Any consideration of the costs of meeting climate objectives requires confronting one of the thorniest issues in all climate-change economics: how should we compare present and future costs and benefits? [...] A full appreciation of the economics of climate change cannot proceed without dealing with discounting."William Nordhaus

\section{Introduction}

Climate change mitigation requires complex thinking and collaboration across various fields - science, engineering, finance, economics, politics, public policy, and law - and across continents. Effective action thus demands the cooperation and collaboration of all institutions. Greenhouse gas (GHG) and carbon (CO2) emissions represent a substantial global risk due to their adverse effects on the climate and by extension to the present and future generations. The extent of the environmental impact from climate change is still uncertain, but recent scientific evidence is increasingly worrisome as documented by the Intergovernmental Panel on Climate Change (IPCC) in 2018. For several years parties to the United Nations Framework Convention on Climate Change (UNFCCC) have raised concerns. The most current global consensus, reflected in the Paris Agreement of December 2015, aims to contain GHG emissions and limit global temperature rise to 2oC or less. Fulfilling these ambitious goals requires considerable and stable resources over time. From December 2009, developed 
countries despite having pledged an annual financial commitment of $\$ 100$ billion to a Green Climate Fund were only able to amass $\$ 10.2$ b contribution to the fund as at January 2019 a shortfall of 98.9 percent and a massive gap from the expected accumulated contribution of $\$ 900 \mathrm{~b}$. Thus, the need to mobilize resources worldwide for climate-compatible investments has become pressing (Anton, 2020).

Climate finance is the study of local and global financing of private and public investment that seeks to support mitigation of, and adaptation to climate change (Hong, Karolyi \& Scheinkman, 2020). Ideas from standard finance theories are being utilized to address climate-change related risks and opportunities for households, corporations and governments birthing an entirely new field referred to as climate or green finance. There is a strong theoretical justification for climate finance. Current climate change issues include the impact of climate change on physical property; financial system fragility-climate change nexus (Carney, 2015); the uncertain social cost of carbon; hedging climate risks; efficiency of capital markets and climate change; beliefs and climate change risks; damage functions; short-termism and corporate emissions. Analytical methods pioneered by luminaries such as Modigliani \& Miller $(1958,1963)$ addressing how a firm's financing choices such as the use of debt rather than equity financing - or vice versa - affects its cost of capital and consequently its investment behaviour including climate-compatible projects; Markowitz's $(1952,1959)$ portfolio theory and the concept of efficient diversification including now of climate-related risks; the seminal asset pricing models of Sharpe (1964), Black (1972), Merton (1973) and numerous multi-factor extensions such as the multi-factor models of Fama-French (2016, 2020), Lambert, Fays \& Hubner (2020), Brennan \& Zhang (2020); efficient market hypothesis and especially option pricing insights are currently being integrated into climate risks analysis. Steffen (2018) and Hong, et al. (2020) attempt to provide a capstone.

Additionally, the marginalization of African countries in the global system of capital accumulation, in climate talks and academic research focusing on the unique nature of the continent concerning sharing the burden of saving the planet, makes African-focused studies imperative. The African continent, comprised of 55 countries, is culturally and economically diverse with different regional economic blocs.

This paper attempts to provide a finance perspective to the subject of climate change in Africa, where climate funding issues are rarely discussed or at best if considered seldom implemented. The continent's financial system lags behind the rest of the world even compared to other developing regions.

\subsection{Some Stylized Facts About the African Economy, Climate Variability and Emissions}

Africa, the second largest continent in terms of landmass and population accounts for $30.4 \mathrm{mkm} 2$ and around 20 percent of the earth's total landmass with a current population of 1.3billion people. Africa is typically segregated into two regions namely: North Africa (which is predominantly affiliated with the Middle East) and Sub-Saharan Africa. The economic and financial systems of African countries are diverse and reviewing such a heterogeneous group presents challenges. For convenience, statistics relating to Sub-Sahara Africa (SSA) which typically excludes Egypt and some North African countries are discussed. Politically, most African economies have made significant advances in freedom and democracy and have democratically elected governments. Comparatively the African continent is the least developed though the economies show some promise. According to the World Bank (World Development Indicators), the 2018 GDP per capita for SSA was \$1,589.2 down from \$1,613.7 in 2008. The average income per capita for OECD countries is over 25 times that of SSA as of 2018. Table 1 below presents GDP per capita (in USD) of some developing regions and selected African countries. SSA has the lowest GDP per capita for the past two decades. Again average growth rate of per capita income over the 19602018 periods is the least. 
Table 1: GDP Per Capita Information

Panel A: GDP Per Capita of Developing Regions of the World (1960-2018, in Current USD)

\begin{tabular}{|c|c|c|c|c|c|c|c|c|c|c|c|c|}
\hline REGION & 1960 & 1970 & 1980 & 1990 & 2000 & 2010 & 2015 & 2016 & 2017 & 2018 & $\begin{array}{l}\text { GROW } \\
2010- \\
2018\end{array}$ & $\begin{array}{l}\text { GROW } \\
1960- \\
2018 \\
\end{array}$ \\
\hline $\begin{array}{l}\text { Sub- } \\
\text { Saharan } \\
\text { Africa }\end{array}$ & 131.5 & 221.5 & 707.9 & 663.1 & 598.0 & 1581.2 & 1674.5 & 1525.5 & 1613.7 & 1589.2 & 0.0006 & 0.0439 \\
\hline $\begin{array}{l}\text { East Asia } \\
\text { \& Pacific } \\
\text { (excluding } \\
\text { high } \\
\text { income) }\end{array}$ & 89.7 & 113.5 & 275.5 & 413.0 & 955.2 & 4001.0 & 6489.3 & 6556.7 & 7083.7 & 7822.4 & 0.0874 & 0.0801 \\
\hline $\begin{array}{l}\text { Europe \& } \\
\text { Central } \\
\text { Asia } \\
\text { (excluding } \\
\text { high } \\
\text { income) }\end{array}$ & NA & NA & NA & 2424.6 & 1782.4 & 7803.2 & 7533.4 & 7176.4 & 8010.7 & 8181.1 & 0.0059 & 0.0444 \\
\hline $\begin{array}{l}\text { Latin } \\
\text { America \& } \\
\text { Caribbean } \\
\text { (excluding } \\
\text { high } \\
\text { income) }\end{array}$ & 358.2 & 580.4 & 2093.5 & 2595.3 & 4223.9 & 8760.3 & 8453.8 & 8136.9 & 8983.9 & 8576.2 & -0.0027 & 0.0563 \\
\hline World & 452.1 & 803.8 & 2531.7 & 4283.0 & 5493.4 & 9541.6 & 10225.5 & 10258 & 10780.8 & 11317.3 & 0.0216 & 0.0571 \\
\hline $\begin{array}{l}\text { OECD } \\
\text { members }\end{array}$ & 1351.2 & 2661.2 & 8880.8 & 17476.7 & 23663.6 & 35986.0 & 36628.9 & 37094 & 38432.2 & 40426.9 & 0.0147 & 0.0603 \\
\hline
\end{tabular}

Panel B: GDP Per Capita of Selected African Countries (1960-2018, in current USD)

\begin{tabular}{|c|c|c|c|c|c|c|c|c|c|c|c|c|}
\hline $\begin{array}{l}\text { Country } \\
\text { Name }\end{array}$ & 1960 & 1970 & 1980 & 1990 & 2000 & 2010 & 2015 & 2016 & 2017 & 2018 & $\begin{array}{l}\text { GROW } \\
2000- \\
2018 \\
\end{array}$ & $\begin{array}{l}\text { GROW } \\
1980- \\
2018 \\
\end{array}$ \\
\hline Egypt & & 233.0 & 500.4 & 765.6 & 1450.5 & 2644.8 & 3599.0 & 3525.0 & 2440.5 & 2549.1 & 0.03 & 0.04 \\
\hline Ghana & 183.4 & 253.6 & 402.1 & 398.6 & 258.5 & 1298.4 & 1766.0 & 1931.4 & 2025.9 & 2202.3 & 0.13 & 0.05 \\
\hline Nigeria & 93.0 & 224.1 & 874.4 & 567.5 & 567.9 & 2292.4 & 2730.4 & 2176.0 & 1968.6 & 2028.2 & 0.07 & 0.02 \\
\hline $\begin{array}{l}\text { South } \\
\text { Africa }\end{array}$ & 443.0 & 834.6 & 2905.8 & 3140.0 & 3032.4 & 7328.6 & 5734.6 & 5272.9 & 6132.5 & 6374.0 & 0.04 & 0.02 \\
\hline
\end{tabular}

Source: World Development Indicators (WDI) 
Figure 1: GDP per Capita (in USD) of Selected African Countries in 2018

\section{8}

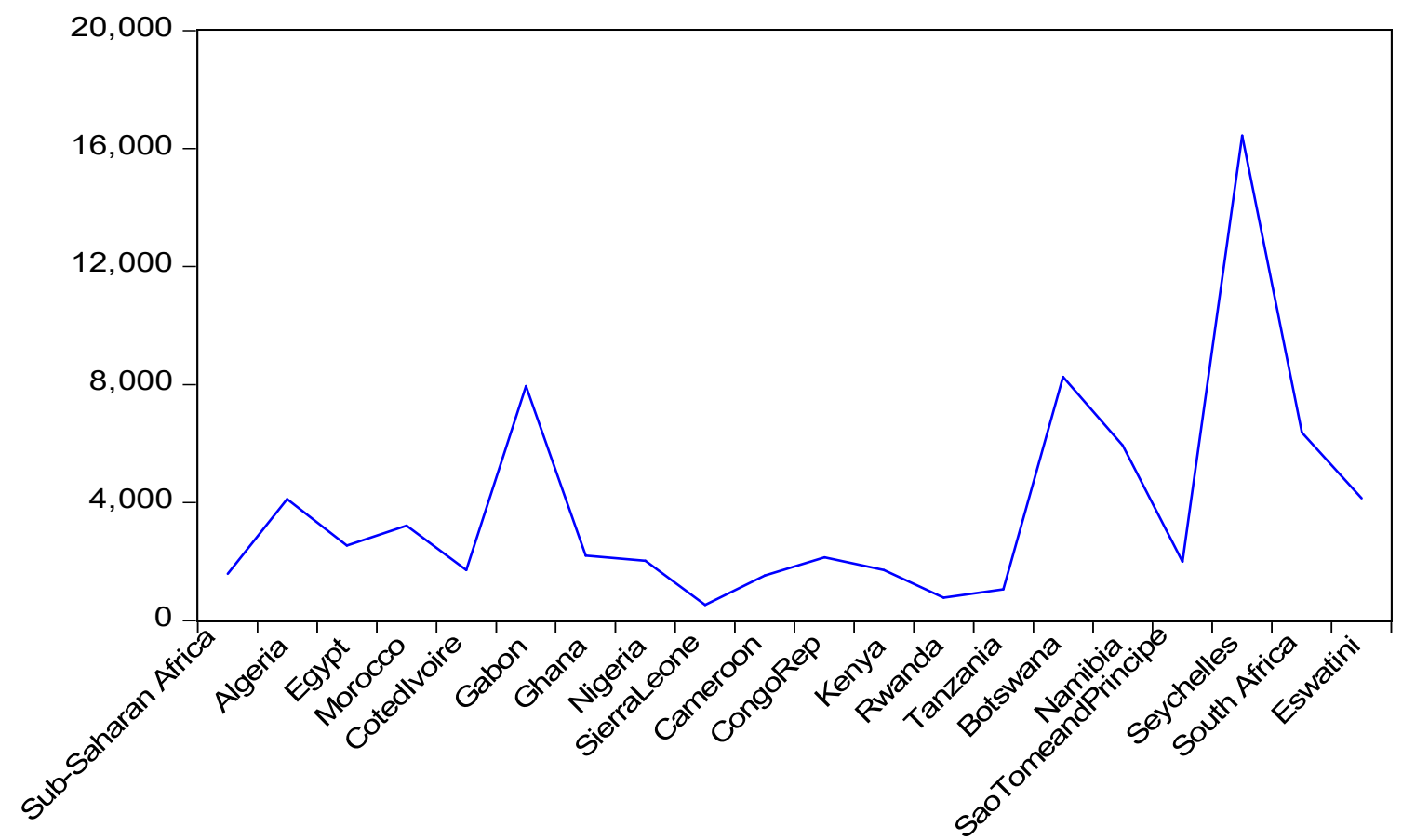

Source: Underlying data from World Development Indicators

Figure 2: GDP per Capita (in USD) of Selected African Countries (1960-2018)

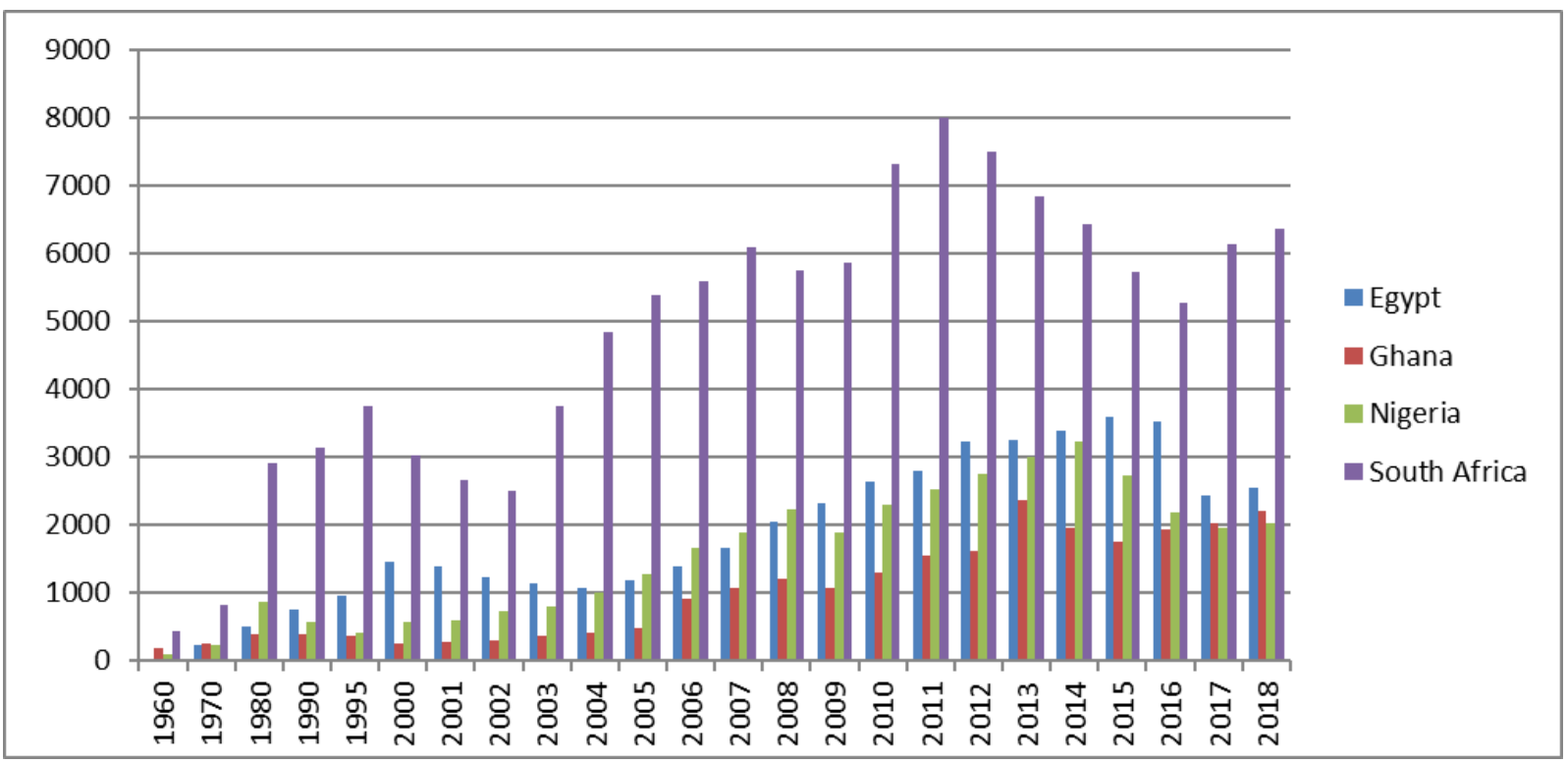

Source: Underlying data from World Development Indicators 
Figure 3: GDP Per Capita in USD Dollars of Sub-Sahara Africa and Other Regions of the World (19602018)

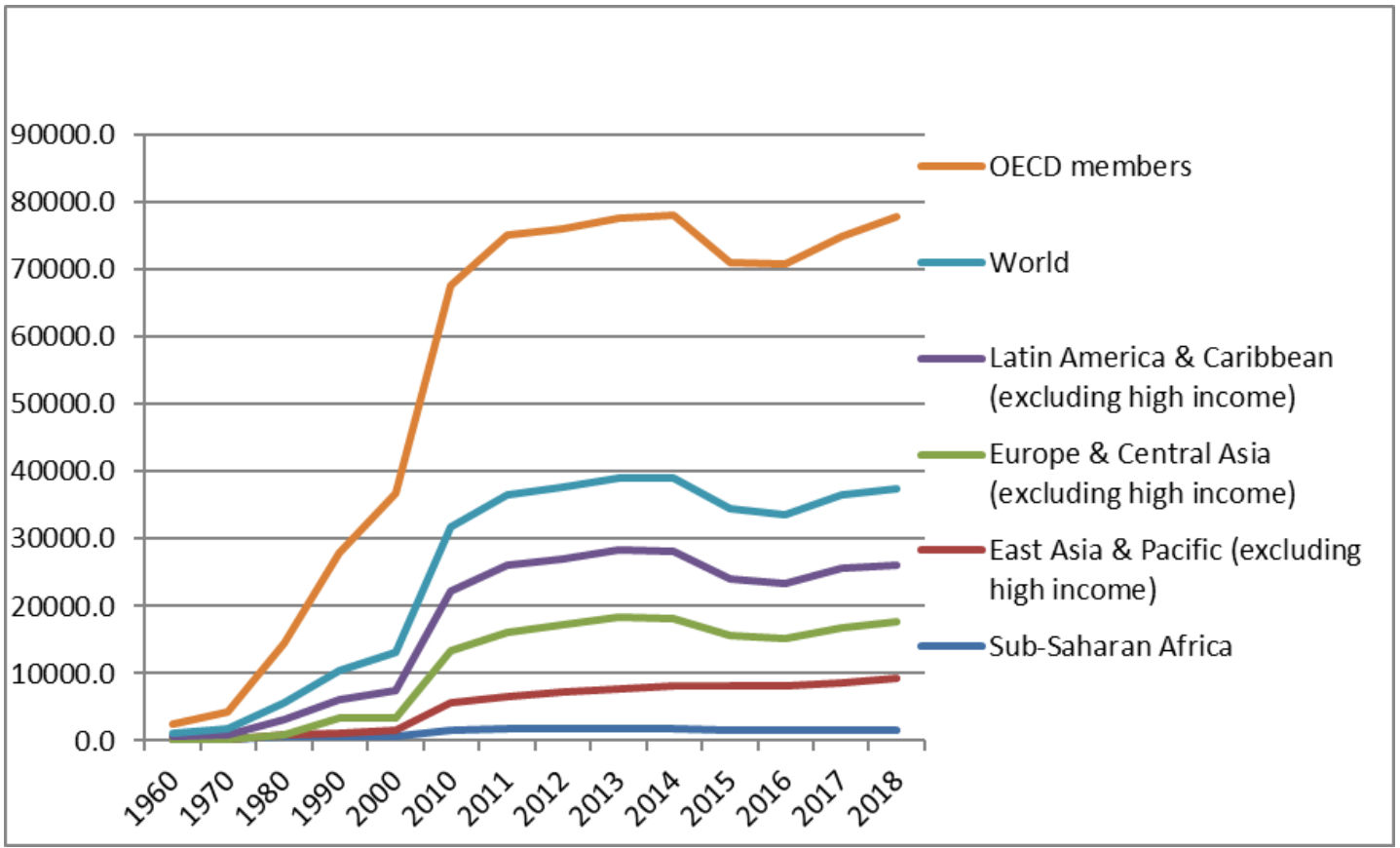

Source: Underlying data from World Development Indicators

Table 2: Selected African Countries' Stock Market Statistics

\begin{tabular}{|c|c|c|c|c|c|c|c|c|c|c|c|}
\hline \multirow[t]{3}{*}{$\begin{array}{l}\text { STOCK } \\
\text { MARKETS } \\
\end{array}$} & & & & & & & & & & \multirow{3}{*}{\multicolumn{2}{|c|}{$\frac{\text { Market liquidity }}{\text { Value of shares traded }}$}} \\
\hline & \multicolumn{9}{|c|}{ Market capitalization } & & \\
\hline & & & & & & & & & & & \\
\hline & \multicolumn{2}{|c|}{$\$$ millions } & & \multicolumn{2}{|c|}{$\%$ of GDP } & & & \multicolumn{2}{|c|}{$\%$ of GDP } & \multicolumn{2}{|c|}{$\%$ of GDP } \\
\hline & 2010 & 2018 & 2005 & 2006 & 2007 & 2008 & 2009 & 2010 & 2018 & 2010 & 2018 \\
\hline Egypt & 84,277 & 42,006 & 89 & 87 & 107 & 53 & 48 & 38.5 & 16.7 & 17 & 5.8 \\
\hline Nigeria & 50,546 & 31,521 & 17 & 22 & 52 & 23 & 20 & 13.9 & 7.9 & 1.4 & 0.7 \\
\hline $\begin{array}{l}\text { South } \\
\text { Africa }\end{array}$ & 925,007 & 865,328 & 233 & 277 & 294 & 178 & 246 & 246.4 & 235 & 73.9 & 80.1 \\
\hline
\end{tabular}

Panel B: Number of Listed Domestic Companies

\begin{tabular}{|c|c|c|c|c|c|c|c|c|c|}
\hline \multirow[t]{3}{*}{$\begin{array}{c}\text { STOCK } \\
\text { MARKET } \\
\text { S } \\
\end{array}$} & & & & \multicolumn{2}{|c|}{$\begin{array}{l}\text { Listed domestic } \\
\text { companies }\end{array}$} & \multicolumn{2}{|c|}{ Listed domestic companies } & \multicolumn{2}{|c|}{ S\&P/Global Equity Indices } \\
\hline & & & & \multicolumn{2}{|c|}{ number } & \multicolumn{2}{|c|}{ number } & \multicolumn{2}{|c|}{$\%$ change } \\
\hline & 2005 & 2006 & 2007 & 2008 & 2009 & 2010 & 2018 & 2010 & 2018 \\
\hline Egypt & 744 & 603 & 435 & 373 & 305 & 227 & 250 & 11.5 & -10.3 \\
\hline Nigeria & 214 & 202 & 212 & 213 & 214 & 215 & 164 & 20.3 & -17.9 \\
\hline $\begin{array}{l}\text { South } \\
\text { Africa }\end{array}$ & 388 & 401 & 422 & 425 & 363 & 352 & 289 & 32.1 & -25.9 \\
\hline
\end{tabular}


Panel C: African Stock Markets and the Rest of the World

\begin{tabular}{|c|c|c|c|c|c|c|c|c|c|c|}
\hline \multirow[t]{3}{*}{$\begin{array}{l}\text { STOCK } \\
\text { MARKETS } \\
\end{array}$} & & & & & & & & & & \\
\hline & \multicolumn{4}{|c|}{ Market capitalization } & \multirow{2}{*}{\multicolumn{2}{|c|}{$\begin{array}{c}\text { Market liquidity } \\
\begin{array}{c}\text { Value of shares } \\
\text { traded }\end{array} \\
\end{array}$}} & \multicolumn{2}{|c|}{ Turnover ratio } & \multicolumn{2}{|c|}{$\begin{array}{c}\text { Listed domestic } \\
\text { companies }\end{array}$} \\
\hline & & & & & & & $\begin{array}{r}\text { Value } \\
\text { tra }\end{array}$ & $\begin{array}{l}\text { shares } \\
\text { ed }\end{array}$ & & \\
\hline & \multicolumn{2}{|c|}{ \$ millions } & \multicolumn{2}{|c|}{$\%$ of GDP } & \multicolumn{2}{|c|}{$\%$ of GDP } & \multicolumn{2}{|c|}{$\begin{array}{c}\% \text { of market } \\
\text { capitalization }\end{array}$} & & \\
\hline & 2010 & 2018 & 2010 & 2018 & 2010 & 2018 & 2010 & 2018 & 2010 & 2018 \\
\hline Algeria & 105 & 371 & 0.1 & 0.2 & & & & & & \\
\hline $\begin{array}{l}\text { Egypt, Arab } \\
\text { Rep. }\end{array}$ & 84,277 & 42,006 & 38.5 & 16.7 & 17 & 5.8 & 44.2 & 34.5 & 227 & 250 \\
\hline Ghana & 2,948 & & 9.2 &. & 0.3 & & 3.5 & & 31 & \\
\hline Nigeria & 50,546 & 31,521 & 13.9 & 7.9 & 1.4 & 0.7 & 10.1 & 8.2 & 215 & 164 \\
\hline $\begin{array}{l}\text { South } \\
\text { Africa } \\
\end{array}$ & 925,007 & 865,328 & 246.4 & 235 & 73.9 & 80.1 & 30 & 34.1 & 352 & 289 \\
\hline $\begin{array}{l}\text { East Asia \& } \\
\text { Pacific } \\
\end{array}$ & $15,942,386$ & $21,718,845$ & 95.1 & 84.7 & 111.6 & 105.1 & 118.5 & 126.9 & 14,151 & 19,025 \\
\hline $\begin{array}{l}\text { Europe \& } \\
\text { Central Asia }\end{array}$ & $9,014,532$ & $11,070,542$ & 61.4 & 75.3 & 48.1 & & 80 & 73.5 & 11,111 & 6,870 \\
\hline $\begin{array}{l}\text { Latin } \\
\text { America \& } \\
\text { Caribbean }\end{array}$ & $2,733,571$ & $1,815,024$ & 61.7 & 40.1 & 25 & 20.8 & 41.5 & 50.3 & 1,283 & 1,181 \\
\hline $\begin{array}{l}\text { Middle East } \\
\& \text { North } \\
\text { Africa }\end{array}$ & $1,061,923$ & $1,419,502$ & 47.8 & 49.3 & 19.8 & 15.2 & 41.1 & 27.6 & 2,119 & 1,957 \\
\hline $\begin{array}{l}\text { North } \\
\text { America } \\
\end{array}$ & $19,456,181$ & $32,376,609$ & 117.1 & 145.5 & 225.3 & 154.6 & 193.1 & 106.1 & 8,064 & 7,740 \\
\hline South Asia & $1,731,377$ & $2,176,448$ & 85.5 & 70.6 & 54.5 & 41.4 & 64 & 57.7 & 6,111 & 5,955 \\
\hline $\begin{array}{l}\text { Sub- } \\
\text { Saharan } \\
\text { Africa }\end{array}$ & & & & & & & 30.4 & 33 & & \\
\hline $\begin{array}{l}\text { Lower } \\
\text { middle } \\
\text { income }\end{array}$ & $2,550,427$ & $3,189,534$ & 63.9 & 57.3 & 32.7 & 27.5 & 54.1 & 45.8 & 7,881 & 7,987 \\
\hline $\begin{array}{l}\text { Upper } \\
\text { middle } \\
\text { income }\end{array}$ & $9,486,182$ & $10,600,667$ & 64.4 & 47.5 & 74.6 & 70.1 & 116.5 & 148.2 & 7,573 & 8,149 \\
\hline $\begin{array}{l}\text { High } \\
\text { income }\end{array}$ & $38,905,252$ & $54,863,886$ & 100.1 & 118.8 & 138 & 120.9 & 138.8 & 98.6 & 28,107 & 27,206 \\
\hline World & $50,941,862$ & $68,654,087$ & 88.5 & 92.9 & 114.7 & 97.8 & 130.9 & 104.7 & 43,561 & 43,342 \\
\hline
\end{tabular}

Source: World Development Indicators

In comparing financial systems, the African economy as a whole is under-developed relative to the rest of the world with regards to the size of the banking system, insurance companies, market capitalization, number of listed securities, stock market liquidity, viable bond and derivatives markets, private equity funds, pension funds and microfinance. Apart from the stock exchanges in table 2, African countries with functional exchanges include Algeria, Botswana, Cote d'Ivoire, Ghana, Kenya, Malawi, Mauritius, Morocco, Namibia, Swaziland, Tanzania, Tunisia, Uganda, Zambia and Zimbabwe.

Bond markets are largely under-developed and where it exists, the secondary bond market is dominated by government securities. No North African economy has a secondary bond market and only the French West African regional market has a corporate bond market. To list on the regional market domiciled in Abidjan, Cote d'Ivoire, named Bourse Regional des Valeurs Mobilieres (BRVM), all bond issues must be guaranteed a financial institution, a development financial institution, a guarantee fund or the parent to an issuing subsidiary company. This bottleneck reduces the popularity of private placements in the French-speaking zone and why they remain unlisted. In terms of corporate borrowing as a means of raising debt finance for most of Africa, bank 
lending dominates corporate issuance of bonds. Nigeria has a Financial Market Dealers Quotation (FMDQ) that provides an arrangement for the trading of debt instruments. Indeed more African banks and financial institutions invest significantly in government securities. This practice reflects a dysfunctional financial intermediation architecture that shuns the private provision of credit. Alternatively, it may reflect the financial institutions' attitude to risk and thus a flight to safety in the face of delinquent credit facilities when prudential ratios are tethering towards the limits imposed by regulators. Adverse macroeconomic conditions especially instability in the economy, are proximate causes of credit risks and banks' reluctance to lend to African businesses. Cultural issues are yet some other reasons for banks' reluctance to lend to seemingly viable businesses as some entrepreneurs show a sheer lack of discipline in managing borrowed funds for businesses.

An area that is getting attention in Africa's policy circles relates to the low levels of development indicators of African stock markets that remain dismal compared with those of other developing parts of the world.There is growing awareness that merely establishing exchanges is useless in the absence of an enabling environment for markets to serve price discovery, liquidity and information production functions. The privatization of erstwhile public enterprises has not helped to significantly raise the depth and liquidity of stock markets to match those of other developing regions. Emerging trends in fundraising being fostered by financial technology companies have brought innovative practices such as crowdfunding for small and medium-scale enterprises in Africa.

It is instructive to note the integration of African economies with the global financial system. Low risk-adjusted returns from the global financial system have triggered investment inflows into African markets. In some instances, the apex banks provide concessionary foreign exchange arrangements for investors and exporters who may need to buy or sell foreign exchange depending on the direction of portfolio decisions.

Table 3: Climate-Change Related Statistics of African Countries and the Rest of the World

Panel A: Climate Variability

\begin{tabular}{|c|c|c|c|c|c|c|c|c|}
\hline & \multicolumn{7}{|c|}{ Exposure to impact } & Resilie \\
\hline & $\begin{array}{l}\text { Land } \\
\text { area } \\
\text { where } \\
\text { elevation } \\
\text { is below } \\
5 \text { meters }\end{array}$ & $\begin{array}{l}\text { Population } \\
\text { living in } \\
\text { areas } \\
\text { where } \\
\text { elevation } \\
\text { is below } 5 \\
\text { meters }\end{array}$ & $\begin{array}{l}\text { Population } \\
\text { affected by } \\
\text { droughts, } \\
\text { floods, and } \\
\text { extreme } \\
\text { temperatures }\end{array}$ & $\begin{array}{l}\text { Urban } \\
\text { land area } \\
\text { where } \\
\text { elevation } \\
\text { is below } \\
5 \text { meters }\end{array}$ & $\begin{array}{c}\text { Rural } \\
\text { population } \\
\text { living in } \\
\text { areas } \\
\text { where } \\
\text { elevation } \\
\text { is below } 5 \\
\text { meters }\end{array}$ & $\begin{array}{l}\text { Rural land } \\
\text { area where } \\
\text { elevation } \\
\text { is below } 5 \\
\text { meters }\end{array}$ & $\begin{array}{c}\text { Urban } \\
\text { populatio } \\
\text { n living } \\
\text { in areas } \\
\text { where } \\
\text { elevation } \\
\text { is below } \\
5 \text { meters }\end{array}$ & $\begin{array}{c}\text { Disaste } \\
\text { r risk } \\
\text { reducti } \\
\text { on } \\
\text { progres } \\
\text { s score }\end{array}$ \\
\hline & $\begin{array}{c}\% \text { of } \\
\text { land area }\end{array}$ & $\begin{array}{l}\% \text { of total } \\
\text { population }\end{array}$ & $\begin{array}{c}\text { average } \\
\text { annual; } \% \text { of } \\
\text { total } \\
\text { population }\end{array}$ & $\begin{array}{c}\% \text { of } \\
\text { urban } \\
\text { land area }\end{array}$ & $\begin{array}{l}\% \text { of rural } \\
\text { population }\end{array}$ & $\begin{array}{l}\% \text { of rural } \\
\text { land area }\end{array}$ & $\begin{array}{c}\% \text { of } \\
\text { urban } \\
\text { populatio } \\
n\end{array}$ & $\begin{array}{c}1, \\
\text { worst } \\
\text { to } \\
5, \text { best }\end{array}$ \\
\hline & 2010 & 2010 & 2009 & 2010 & 2010 & 2010 & 2010 & 2011 \\
\hline Algeria & 0 & 0.8 & 0 & 0 & 0.2 & 0 & 0.6 & 3.5 \\
\hline Egypt & 1.6 & 21.5 & 0 & 0.3 & 12.3 & 1.3 & 9.3 & \\
\hline Ghana & 0.6 & 2.6 & 1 & 0.1 & 0.8 & 0.5 & 1.8 & 3.3 \\
\hline Nigeria & 0.4 & 2.7 & 0.1 & 0 & 0.7 & 0.4 & 2 & 4 \\
\hline South Africa & 0.1 & 0.2 & 1.8 & 0 & 0.1 & 0.1 & 0.1 &.. \\
\hline $\begin{array}{l}\text { Sub-Saharan } \\
\text { Africa }\end{array}$ & 0.4 & 1.9 & & 0 & 0.7 & 0.4 & 1.2 & \\
\hline $\begin{array}{l}\text { Middle East \& } \\
\text { North Africa }\end{array}$ & 0.7 & 7.1 & & 0.1 & 3.4 & 0.6 & 3.7 & \\
\hline $\begin{array}{l}\text { East Asia \& } \\
\text { Pacific }\end{array}$ & 1.5 & 8.3 & .. & 0.2 & 3.7 & 1.3 & 4.6 &.. \\
\hline World & 1.1 & 5 & & 0.1 & 2.2 & 1 & 2.8 & \\
\hline
\end{tabular}


Panel B: Trends in Carbon-dioxide $\left(\mathrm{CO}_{2}\right)$ and Greenhouse Gas (GHG) Emissions

\begin{tabular}{|c|c|c|c|c|c|c|c|c|c|c|c|c|}
\hline \multirow[t]{4}{*}{$\begin{array}{l}\text { TRENDS IN } \\
\text { CO2 AND GHG } \\
\text { EMISSIONS } \\
\end{array}$} & \multicolumn{10}{|c|}{ Carbon dioxide emissions } & \multicolumn{2}{|c|}{$\begin{array}{c}\text { Total greenhouse gas } \\
\text { emissions }\end{array}$} \\
\hline & \multicolumn{2}{|c|}{$\begin{array}{l}\text { Electricity and heat } \\
\text { production }\end{array}$} & \multicolumn{2}{|c|}{$\begin{array}{l}\text { Manufacturing industries } \\
\text { and construction }\end{array}$} & \multicolumn{2}{|c|}{$\begin{array}{l}\text { Residential buildings } \\
\text { and commercial and } \\
\text { public services }\end{array}$} & \multicolumn{2}{|c|}{ Transport } & \multicolumn{2}{|c|}{ Other sectors } & & \\
\hline & \multicolumn{2}{|c|}{$\begin{array}{l}\% \text { of total fuel } \\
\text { combustion }\end{array}$} & \multicolumn{2}{|c|}{$\begin{array}{l}\% \text { of total fuel } \\
\text { combustion }\end{array}$} & \multicolumn{2}{|c|}{$\begin{array}{l}\% \text { of total fuel } \\
\text { combustion }\end{array}$} & \multicolumn{2}{|c|}{$\begin{array}{l}\% \text { of total fuel } \\
\text { combustion }\end{array}$} & \multicolumn{2}{|c|}{$\begin{array}{l}\% \text { of total } \\
\text { fuel } \\
\text { combustion }\end{array}$} & $\begin{array}{l}\text { thousand } \\
\text { metric tons } \\
\text { of carbon } \\
\text { dioxide }\end{array}$ & $\begin{array}{c}\% \\
\text { chang }\end{array}$ \\
\hline & 1990 & 2014 & 1990 & 2014 & 1990 & 2014 & 1990 & 2014 & $\begin{array}{c}199 \\
0\end{array}$ & $\begin{array}{c}201 \\
4\end{array}$ & 2012 & $\begin{array}{l}1990- \\
2012\end{array}$ \\
\hline Algeria & 45.1 & 38.8 & 11.1 & 8.3 & 12.9 & 15.2 & 30.9 & 35.3 & 0 & 2.4 & $176,471.20$ & 65.8 \\
\hline $\begin{array}{l}\text { Egypt, Arab } \\
\text { Rep. }\end{array}$ & 32.6 & 50.3 & 34.2 & 15.2 & 12.5 & 8.4 & 20.8 & 22.5 & 0 & 3.5 & $295,499.70$ & 112.4 \\
\hline Ghana & 2.8 & 24.3 & 11.8 & 12.6 & 17.3 & 5.9 & 63.8 & 55.4 & 4.7 & 1.8 & $107,784.30$ & 265.4 \\
\hline Nigeria & 29.4 & 39.1 & 13.6 & 12.2 & 15 & 2.6 & 41.9 & 35.4 & 0 & 10.8 & $301,010.10$ & 84.4 \\
\hline South Africa & 59.8 & 67.5 & 22.2 & 12.6 & 4.6 & 5.5 & 12.1 & 12 & 1.2 & 2.4 & . & 43.8 \\
\hline $\begin{array}{l}\text { Sub-Saharan } \\
\text { Africa }\end{array}$ & 50.8 & 54.8 & 21.7 & 13 & 6.4 & 6.1 & 18.9 & 22.9 & 2.1 & 3.3 & $4,601,155.10$ & 35.5 \\
\hline $\begin{array}{l}\text { Middle East \& } \\
\text { North Africa }\end{array}$ & 39.7 & 46.9 & 21.1 & 18.4 & 10.3 & 8.7 & 26.1 & 24.6 & 2.8 & 1.3 & $1,464,934.50$ & 44.6 \\
\hline $\begin{array}{l}\text { East Asia \& } \\
\text { Pacific } \\
\end{array}$ & 38 & 52.4 & 30.7 & 27.7 & 14.3 & 5.7 & 12.9 & 12.3 & 4.2 & 1.9 & $\begin{array}{r}18,822,910.6 \\
0 \\
\end{array}$ & 104.7 \\
\hline World & 43.3 & 49 & 20 & 20 & 13.1 & 8.6 & 20 & 20.4 & 3.7 & 2 & $\begin{array}{r}53,526,302.8 \\
0 \\
\end{array}$ & 40 \\
\hline
\end{tabular}

Panel C: Deforestation and Biodiversity

\begin{tabular}{|c|c|c|c|c|c|c|c|c|c|c|}
\hline $\begin{array}{l}\text { DEFORESTATI } \\
\text { ON AND } \\
\text { BIODIVERSIT }\end{array}$ & \multicolumn{2}{|c|}{ Forest area } & \multicolumn{4}{|c|}{ Threatened species } & \multirow[t]{2}{*}{$\begin{array}{l}\text { Terrestrial } \\
\text { protected } \\
\text { areas }\end{array}$} & \multirow{2}{*}{$\begin{array}{l}\text { Marin } \\
\text { e } \\
\text { protec } \\
\text { ted } \\
\text { areas } \\
\end{array}$} & & \\
\hline & & & Mammals & Birds & Fishes & $\begin{array}{l}\text { Higher } \\
\text { plants }\end{array}$ & & & & \\
\hline & sq. km & ssands & & & & & $\begin{array}{l}\% \text { of total } \\
\text { land area }\end{array}$ & $\begin{array}{c}\% \text { of } \\
\text { territo } \\
\text { rial }\end{array}$ & & \\
\hline & 1990 & 2016 & 2018 & 2018 & 2018 & 2018 & 2017 & 2017 & & \\
\hline Algeria & 17 & 20 & 14 & 15 & 41 & 22 & 7.5 & 0.1 & & \\
\hline $\begin{array}{l}\text { Egypt, Arab } \\
\text { Rep. }\end{array}$ & 0 & 1 & 18 & 14 & 58 & 8 & 13.1 & 5 & & \\
\hline Ghana & 86 & 94 & 21 & 23 & 58 & 119 & 15.1 & 0.1 & & \\
\hline Nigeria & 172 & 66 & 31 & 21 & 74 & 205 & 13.9 & 0 & & \\
\hline South Africa & 92 & 92 & 30 & 54 & 121 & 153 & 8 & 12.1 & & \\
\hline World & 41,283 & 39,958 & 3,434 & 4,584 & 8,233 & 15,735 & 14.7 & 11.4 & & \\
\hline $\begin{array}{l}\text { Sub-Saharan } \\
\text { Africa }\end{array}$ & 6,516 & 6,115 & 967 & 993 & 2,064 & 4,862 & 17.7 & & & \\
\hline $\begin{array}{l}\text { East Asia \& } \\
\text { Pacific }\end{array}$ & 6,280 & 6,421 & 934 & 1,224 & 1,630 & 3,799 & 16.5 & 16.9 & & \\
\hline $\begin{array}{l}\text { Europe \& } \\
\text { Central Asia }\end{array}$ & 10,200 & 10,439 & 350 & 678 & 1,239 & 1,306 & 11.7 & 5.5 & & \\
\hline $\begin{array}{l}\text { Latin America } \\
\& \text { Caribbean }\end{array}$ & 10,242 & 9,251 & 629 & 1,117 & 1,716 & 5,439 & 23.5 & 17.5 & & \\
\hline $\begin{array}{l}\text { Middle East \& } \\
\text { North Africa }\end{array}$ & 199 & 232 & 228 & 290 & 672 & 374 & 6.7 & 1.6 & & \\
\hline North America & 6,507 & 6,574 & 62 & 118 & 322 & 536 & 11.3 & 20.8 & & \\
\hline South Asia & 789 & 835 & 252 & 253 & 397 & 794 & 7.3 & 0.5 & & \\
\hline Low income & 3,775 & 3,513 & 649 & 663 & 1,172 & 3,038 & 15.9 & & & \\
\hline
\end{tabular}




\begin{tabular}{|l|r|r|r|r|r|r|r|r|r|}
$\begin{array}{l}\text { Lower middle } \\
\text { income }\end{array}$ & 6,539 & 5,991 & 1,120 & 1,286 & 2,018 & 3,789 & 13.6 & 1.6 & \\
\hline $\begin{array}{l}\text { Upper middle } \\
\text { income }\end{array}$ & 20,451 & 20,195 & 1,092 & 1,632 & 2,417 & 7,390 & 14.7 & 7.7 & \\
\hline High income & 9,969 & 10,167 & 561 & 1,092 & 2,433 & 2,893 & 15.1 & 23.2 & \\
\hline
\end{tabular}

Source: Underlying Data from the World Development Indicators

Table 3 confirms Africa is not the primary source of global warming given that despite accounting for 16 percent of the world population, it contributes only $8.6 \%$ of global emissions. Additionally, Africa's forest area constitutes an enormous tool for carbon sinks, merely representing $15.3 \%$ of worldwide forest area in square meters. The cooperation of developing countries is required to meet climate targets with inevitable trade-offs.

\section{The Imperatives for Climate Finance}

2.0 Why Is Climate Change and Finance Important for African Countries?

In business, life and politics, it is essential to follow the money. Finance is relevant to climate discussions as it borders on the transition from carbon-intensive activities to those that less reliant on carbon-intensive energy sources while adapting to the residual risks. Climate action requires committing finances for desirable long-term environmental benefits as finance enables countries funding and take bold steps to lower greenhouse gas (GHG) emissions.

Despite the potentially devastating effects of climate-related challenges on Africa, Africa has remained primarily marginalized in global climate discussions. Issues like financial systems fragility and potential transmission outside the continent; internal displacement (Adeola, 2020); urban vulnerability (Mapitsa, 2020); intra-regional conflicts and migration (Olutola, 2020; Adeniran, 2020); and the challenges of reintegration of refugees and internally displaced persons in Africa (Owigo \& Yusuf, 2020) remain topical. Bernstein, Gustafson \& Lewis (2019) provide evidence that homes exposed to flooding due to climate-induced sea-level rise suffer approximately 7 percent decline in value relative to unexposed properties of similar quality equidistant to the beach. Besides, there are concerns about incorporating the risk of rising sea levels in residential real estate property (Murfin \& Spiegel, 2020). In Lagos, Nigeria, such environmental risks are rarely reflected in the pricing of real estate at the Lekki-Ajah-Epe axis. There are flood risks imminent for properties situated near the beaches. The inconveniences and predicament of residents and employees of companies located within the axis are better imagined than described during the rainy season.

\subsection{Climate Change Is a Source of Financial Risk}

There is a growing consensus among international financial regulators that climate change presents real financial risks. Indeed, preliminary studies support the notion that increased climate change may increase the frequency of banking crises. The largest American financial institutions appear more vulnerable to climate change given their roles as capital providers to industries driving climate change through lending, underwriting, investing, or some combination (Steele, 2020, Hong, Karolyi \& Scheinkman, 2020). Proponents like Carney who support the climate-financial fragility view proffer that adverse climate poses fragility to the financial system given the damaging impact on the physical property (Carney, 2015; Giglio \& Xu, 2019; Giglio, Maggiori, Stroebel, Weber, 2019). Thus, climate change policies carry inherent financial risks through disruptions to business models (Engle et al., 2020), and may exacerbate the credit risk of financial transactions, impair financial markets, and pose long-term damaging effects

\section{A. Climate Risk Damages Property, Plant and Equipment (PPE)}

PPEs are tangible items held for use in the production or supply of goods and services or rental or administrative purposes for more than one fiscal or accounting period. The damaging impact of adverse climatic conditions on PPEs and other physical assets financed by financial institutions could be enormous. Physical risk on PPEs 
includes weather-induced damage on real estate that may have been held as collateral for mortgages and other loans (Murfin \& Spiegel, 2020), damage to crops on farmlands that may have been held as security for agricultural loans. Others include weather-induced sea levels rise flooding residential, commercial or industrial locations and leading to the resettlement of persons and "stranded assets," or wildfires burning factory buildings held by firms with business loans (Baldauf, Garlapp \& Yannelis, 2020). Physical risks can be either "acute," caused by short-term but extreme events or "chronic," long-lasting and long-developing (Steele, 2020).

\section{B. Policy Pathways to Address Climate Change Embody Financial Risks}

Indeed, policy pathways to address climate change embody financial risks as the transition from a carbonintensive economy to a low carbon economy such as the transition from fossil fuels to renewable clean energy comes with risks and increased costs for households, corporations and governments. The policy-induced transition risks include the decline in revenue, cash flows, the market value of fossil fuel businesses, and the financial impacts on specific geographic regions and communities in Africa (Adeniran, 2020; Olutola, 2020) and elsewhere. For instance, the transition to a clean energy economy is partly responsible for the decline in crude oil prices in the international market with an adverse impact on the revenue of oil-exporting African economies. Beyond the impact on commodity prices and certain derivatives, the value of equities and debt securities of these fossil-fuel-based businesses typically plummet.

The range and timing of possible transition pathways depend upon policy-making processes and the political processes that drive policy priorities. To appreciate the inherent uncertainty in such a situation, consider the substantial risks and unpredictability in the political responses to the global financial crisis, and then find that political and policy decisions in the U.S. and European countries have only become less predictable the decade since the global financial crisis. Many African fiscal and monetary authorities closely follow Europe and America's macroeconomic policies in determining appropriate national policy response to shocks. Attempts to forecast likely transition pathways and policy responses to the climate crisis necessarily combine the volatility of the current political moment with the uncertainty of climate science.

The nature of any transition also depends on the actions taken by financial institutions and other market participants, which have incentives to maximize short-term profitability, share price, and bonus payouts over long-term interests. While there are isolated examples of institutions taking incremental steps to address climate risk, many African financial institutions - from banks to insurers — still fail to either fully account for the various financial risks of climate change, or take affirmative steps to mitigate such risks fully. In one example, African financial institutions lag the rest of the world in implementing policies and practices around financing the commodities that drive deforestation. Though many have ratified climate treaties like the Equator Principles a little probe on their understanding of these principles and how they apply to credit and operating decisions will uncover an inadequate knowledge and lack of commitment. Perhaps there is no better illustration of the current moderate pace of the financial industry's ongoing transition efforts than the fact that the largest banks and asset managers have increased their holdings of fossil fuel assets in the wake of the landmark Paris Agreement. Perhaps they argue that the most significant contributors to GHG and $\mathrm{Co} 2$ emissions are non-Africans - the most industrialized nations of the world who may continue to pollute the planet and free ride on environmental cooperation of the least $\mathrm{CO} 2$ emitters. Most benefits of clean energy and sustainable projects are global and distant while the associated costs are local and immediate (Nordhaus, 2015; Gollier \& Tirole, 2015).

Physical and transition risks have the potential to compound risk because climate change causing activities, in a mutually reinforcing dynamic creates and exacerbates both types of risk. The Dynamic Integrated ClimateEconomy (DICE) model and its integrated regional variant (RICE) may be well suited to quantify the costs and benefits of transition toward slowing greenhouse warming. The higher the level of financial institutions' investments in fossil fuels, the more climate change that they cause, potentially leading to more actual damage to their investments. At the same time, financial institutions' continued investment in fossil fuel and deforestation related assets makes the transition to a clean energy economy more difficult as the stakes and associated vested interests get higher. The physical and transition risks of climate change can manifest in financial institutions through credit risk, market risk, or both. 


\section{Climate Risks Affect the Credit Risks of Financial Transactions}

Credit risk is the possibility of loss to lenders and financial institutions arising from the borrowers' default or not meeting contractual obligations. Thus, the insolvency and bankruptcy of a significant obligor whose line of business is fossil fuel dependent and at the same time experience a climatic shock to the business model may lead to default. A climatic collapse may undermine financial conditions and by extension, the creditworthiness of the affected firm(s). Given efficient capital markets, the market values of such climate-sensitive or impacted sectors will decline through ratings downgrade or outright share price fall. Falling share prices would increase (market) leverage ratios despite the firms not issuing new debt - a situation may constrain the firms' ability to raise external finance, which generally results in the familiar under-investment problem (Myers, 1977). Even firms that might not directly finance individual businesses that drive climate change may have exposure to affected sectors and regions. Under the International Financial Reporting Standards number 9 (IFRS 9), such financial fragility situations and the credit risks they pose are required to be anticipated and applied in recognition of losses and valuation of financial instruments including loans. Thus, the ex-ante impact of climate risks on the financial statements of banks and other financial institutions may be significant and could exacerbate underlying financial fragility conditions in many developing countries. Thus, climate risk can lead to both a higher probability of default and higher potential losses given default.

\section{Climate Risks Can Impair Financial Markets}

Roll (1984) considers the geographic concentration of orange juice (OJ) in Orlando, Florida as a result of relatively stable weather in that location. He finds that the market price of frozen concentrated orange juice is affected by climate, such as unusually cold temperatures. According to him, "weather is the most obvious and significant influence on the orange crop"(Roll, 1984: 879). The vulnerability of African corporations' production processes to natural disasters amplified by climate change can negatively impact corporate profitability and cash flows with direct transmission to the capital markets (Barro, 2015; Hong, Li \& Xu, 2019). These effects transmit to equity and bond markets in terms of liquidity, price discovery and operational efficiency. Market disruptions can lead to asset devaluations or the "stranded asset problem" and the market dynamic known as a "fire sale," where market participants simultaneously seek to monetize assets that are declining in value, leading to further devaluation. In the face of potential disruptions to well-functioning capital markets for bonds and equities, the innovative financing instruments such as Green Bonds may arise. Indeed some African countries have issued Green Bonds to finance clean energy and other climate-compatible activities. Nigeria, the largest African economy, released its first Green Bond in 2017 to fund critical infrastructure projects.

E. Climate change-related losses have a high probability of materializing and a potentially long duration.

While the appropriateness of considering the probability that risks will materialize is a matter of ongoing debate, as discussed more below, it is worth considering that the likelihood of financial risks from climate change emerging is high, if not a certainty. Research suggests that capital markets assets like equities are already losing value as a result of climate change. From 1970 to 2012 , a $1^{\circ} \mathrm{C}$ increase in temperature resulted in a decline in equity valuation of approximately five percent, and the losses caused by temperature increase have become higher over time (Steele, 2020; Choi, Gao \& Jiang, 2020). Since 2011, the Dow Jones U.S. Coal Index has fallen by over 85 percent. BlackRock, the world's largest asset manager, has lost investors over $\$ 90$ billion in value destruction and opportunity cost by ignoring climate risk in its investment strategies over the last decade. In the insurance sector alone, inflation-adjusted climate-related losses have increased from an annual average of around $\$ 10$ billion in the 1980 s to approximately $\$ 55$ billion over the past decade. One big question on climate disaster and investment borders on whether asset managers correctly estimate climatic disaster risks (Barro, 2015; Alok, Kumar, \& Wermers, 2020). In 2018, the U.S. experienced 14 separate billion-dollar weather and climate disaster events, with a total cost of at least \$91 billion. Insurance companies paid out an estimated \$219 billion in natural disaster-related claims over 2017 and 2018, the highest for any two years in history.

Some future climate losses are already "baked in" the atmosphere, as the climate is projected to warm by $1.1^{\circ} \mathrm{F}$ over the next century solely based upon emissions that are already in the atmosphere. Furthermore, meeting the 
Paris Climate Accord goals, or better yet even more aggressive emission reduction targets, would require significant reductions in carbon emissions, possibly to zero or negative, by 2040. Thus, the likelihood of further financial impacts from either climate change itself, or the accompanying policy response, far exceeds the estimates of tail events predicted by economic models before the 2008 crisis.

Unlike other financial crises and recessions that last for months or years, many of the risks arising from climate change are irreversible and will last for a long time. Indeed, the National Climate Assessment warns that "without substantial and sustained global mitigation and regional adaptation efforts, climate change is expected to cause growing losses to American infrastructure and property and impede economic growth rate over this century." It continues: "climate change resulting from human-caused emissions of carbon dioxide will persist for decades to millennia." This suggests that the types of short-term interventions that have sufficed to stabilize financial markets during previous panics will not stem the potential damage caused by climate change.

\subsection{Climate Change is a Threat to the Stability of the Financial System}

While the concept of "systemic risk" does not have a single legal definition, it can be summarized as the "impairment of financial intermediation or financial market functioning that would be sufficiently severe to inflict significant damage on the broader economy." The financial risks of climate change do not just have the potential to rise to a systemic risk based on the various factors outlined above. Those attributes, as well as others discussed below, mean that, like other sources of systemic risk, climate risk is likely to manifest in ways that are unpredictable, difficult to contain, and create externalities and moral hazard. Importantly, the proper conceptual framework for evaluating potential threats to financial stability is not to wait for the risks to come to fruition. Instead, we must preemptively launch an inquiry into a range of prospective climate crisis scenarios, and seek to anticipate how such situations might be prevented.

A. Systemic risk is transmitted through either financial assets or institutions. Systemic risk is transmitted through direct financial exposures between institutions or common indirect vulnerabilities that institutions have to particular asset classes. The financial industry is deeply interconnected, and, as a result, risk - particularly climate risk - can be transmitted within and across sub-sectors via either of these channels.

I. Climate financial risk can be transmitted through systemic counter parties

In the counter-party transmission channel, when vulnerable financial markets and financial institutions are exposed to one another, losses or the threat of failures at a single large counter-party leads to runs and fragility at other counter-parties. For example, the $\$ 182$ billion bailouts of insurer AIG was necessary for the part to protect the counter-parties to AIG's over-the-counter credit default swap contracts from experiencing distress themselves.

Ultimately, a catastrophic climate event that impacts credit or market risk can start a panic that leads to funding pressure, depletion of capital, and insolvency at a large financial institution or group of institutions. These events would then trigger defaults on payments to counter-parties, many of which may themselves be both systemic and experiencing financial distress. This transmission channel is particularly relevant when considering the systemic footprints of large bank holding companies, asset managers, and insurers, an evaluation that includes interconnectedness as a factor. At the same time, most systemic financial institutions also contribute the most and have the most exposure to climate change.

II. Climate financial risk can be transmitted through vulnerable asset classes. For example, through the asset liquidation channel, several financial firms hold the same assets, and by extension, the entire financial system, experience fragility, leading to runs or fire sales that decrease the value of those assets and thereby endanger the value of firms' capital. Examples of financial markets that experienced this dynamic in the 2008 financial crisis include money market mutual funds and commercial paper. Climate risk can be transmitted through a sudden revaluation of asset classes that destabilizes the financial sector; a significant climate event could trigger such an event. Counter-intuitively, it could also be triggered by financial institutions' efforts to mitigate their exposure to 
such an event, for example, by suddenly exiting short-term assets that are exposed to climate risks. It can also result in stranded assets that are no longer productive in the real economy.

Engle, Giglio, Kelly, Lee \& Stroebel (2020) implement a procedure to dynamically hedge climate risk through textual analysis of newspapers to extract innovations from climate news series. Engle et al. (2020) utilized insights from portfolio theory, options and asset pricing to build climate change hedge portfolios and showed that their method yields industry-balanced portfolios that perform well in hedging innovations in climate news both in-sample and out-of-sample.

\section{B. Analyzing Climate Risks through Systemic Risk Factors}

In determining whether a financial activity can "amplify potential risks to U.S. financial stability" (Steele, 2020), the risk factors that can turn climate change into a systemic phenomenon should be considered adequately. The FSOC considers the following attributes: credit risk; leverage, including from derivatives; liquidity or maturity mismatch; counter-party risk or interconnectedness; transparency; and the risk of destabilizing particular financial markets. While the credit and market risks associated with climate change have already been unpacked above, the other factors will be discussed below. Besides, it is vital to consider whether an activity is "highly concentrated or significant and widespread[.]" Using this framework, the systemic nature of climate changedriving financial activities comes into greater focus.

I. Climate risk involves leverage, including derivatives.

Exposures to climate change can come through a variety of financial products that are complex, opaque, and insufficiently regulated. Large financial institutions trade a variety of securities and derivatives exposed to climate risks and derive their value from industries that produce climate risk.

For example, the four largest U.S. bank derivatives dealers are currently exposed to $\$ 929$ billion in notional value of commodity swaps contracts. The vast majority of these contracts are traded over-the-counter and, therefore, do not benefit from the default risk-mitigating effects of central clearing. Though a small percentage of the overall derivatives market, these transactions are "where the greater risks and capital subsidy is most useful to these banking firms." The derivatives market in Africa is still primarily dominated by over-the-counter contracts being arranged or facilitated by deposit money banks while the exchange-traded derivatives are rare.

Besides, the energy industry derives significant funding from products like leveraged loans and collateralized loan obligations, which often have low credit ratings, trade in less liquid markets, and have begun declining in value in recent months. Even efforts to "hedge" their perceived risks from climate change can increase financial risk, as hedging itself creates exposures through financial instruments that can introduce additional sources of exposure (Engle et al. 2020). For example, individual institutions attempting to hedge different risks using products like "weather derivatives" can create and spread additional risks across other institutions or sectors. Recall the role that the ineffective hedging of subprime mortgage risk played in 2008 when institutions protected themselves from losses on mortgage-backed securities and structured mortgage products by buying credit default swap protection from AIG. Margin calls from AIG's credit default swap counter-parties created funding problems, and, as noted above, the AIG bailout was necessary partly to protect its counter-parties from experiencing distress themselves. In terms of valuation of contingent claims, insights from the well-known Black-Scholes (1973) option pricing model can be applied to determine the prices of the option-embedded assets and liabilities being carried on firms' balance sheets.

II. Climate risk is vulnerable to liquidity or maturity mismatch.

There are various ways in which climate change could create pressures that exacerbate the mismatch between institutions' assets and liabilities or the liquidity of relevant markets. For example, as discussed earlier, the decline in the value of certain climate-exposed assets held by investment funds can lead to fire sales, stranded assets, or redemption of the interests in such funds due to climate-related concerns create runs. Securities markets, however, are not the only source of potential mismatches. On the lending side, as noted above, if a 
critical mass of banks simultaneously sought to exit their short-duration loans based on potential or actual climate exposure, it would likely impair those markets. It is also important to remember that 30 -year mortgages are long-term assets that must be paired with property and casualty insurance policies renewed every year, creating duration mismatch. A repricing of, or failure to renew, homeowner insurance policies could have implications for borrowers' ability to repay their loans, leading to delinquencies or defaults. It could also affect current or future mortgage assets in particularly climate-exposed areas (Steele, 2020; Barnett, Brock \& Hansen, 2020; Bernstein, Gustafson \& Lewis, 2019).

Big financial institutions also make private equity investments in industries exposed to catastrophic and transition risks and trade commodities that drive climate change, all of which may not be subject to sufficient oversight and regulation. The largest bank holding companies have used this authority to develop stockpiles of climate change driving fossil fuels, including coal, crude oil, heating oil, ethanol, fuel oil, gasoline, jet kerosene, naphtha, natural gas, electricity, and agricultural products. In addition to being some of the most environmentally sensitive exposures on an institution's balance sheet, these assets are often difficult to value and do not have a readily available liquid market if they need to be monetized.

Finally, certain climate-exposed commodity transactions are structured as short-term secured contracts, such as repurchase agreements or "repos," using the underlying commodities, such as barrels of oil or metals, as collateral. A run on specific repo markets was a significant component of the 2008 financial crisis. Should specific commodity markets become impaired due to climate-related events, it could create financing pressures similar to those experienced during the crisis.

\section{Climate risk creates counter-party risk and interconnectedness.}

Interconnectedness measures the degree of market participants' exposure to one another. Climate financial risk is highly interconnected because it is not isolated to a specific financial sector or market. Through either the direct or indirect transmission channel, climate risk can trigger spillover risks and feedback loops, creating contagion across various portfolios and asset classes simultaneously. For example, property and casualty insurers' unwillingness to insure specific properties would have implications for real estate-collateralized lending (Murfin \& Spiegel, 2020). Likewise, solvency issues at property and casualty insurers that lead to an inability to pay claims could impact the credit risk of real property-collateralized loans by banks.

Even financial products that are intended to hedge climate risks can create interconnectedness. For example, catastrophe bonds are meant to spread catastrophic payment risk to financial actors who are not exposed to such risks and rely on the assumption that such risk is uncorrelated to other financial market risks. However, if climate events coincide with other financial market disruptions, catastrophe bonds could amplify, rather than reduce the associated risks. Painter (2020) examines the municipal bond market, comparing the underwriting fees and yields of climate-change exposed counties relative to the less exposed counties. It also finds that climate change risks for market prices is for long-term securities only.

Finally, the three largest asset managers are also the largest shareholders in three of the four largest U.S. banks. This exposure can flow two ways: significant losses at bank holding companies would have a detrimental impact on the value of asset managers' holdings. In contrast, instability at an asset manager could necessitate fire sales of bank equities leading to distress in the banking sector. Given the significant exposures that each industry has to climate risk, climate-related events can create contagion that spreads from asset managers to banks or vice versa. Climate risk can be a particularly significant source of contagion because a deeply interconnected financial system is layered on top of interconnected economic sectors, which is then layered atop interconnected earth systems. The interdependencies between the sectors and systems exposed to the climate, such as energy, water, and agriculture, and those less directly exposed to the climate, like the financial sector, "can lead to complex behaviors and outcomes that are difficult to predict." Investors' sentiments towards ethical and green investing can exert a significant impact on portfolio choice. For instance, Das, Fuss, Hanle \& Russ (2020) recently show that sentiments and returns in housing and stock markets exhibit a strong dependence on financial markets. In contrast, they evolve independently in commercial real estate. 
IV. Climate risk lacks sufficient transparency and contains a high degree of uncertainty.

The corporate sector's climate disclosure efforts have primarily been driven by social responsibility and sustainability, rather than financial risk management. Also, the dirtiest industries mainly already comply with disclosure best practices, proving the insufficiency of such measures. Rather than addressing this opacity, the current FSOC has shown no interest in publicly raising the financial risks of climate change, or disseminating any information about it.

Information gaps lead to panics and runs, particularly in the absence of shock-absorbing prudential regulations. Opacity about potential exposures contributes to crises and panics, as it did when regulators and market participants sought to gauge the scale of financial institutions' exposures to mortgage-related assets in 2008. As demonstrated by the stress testing discussion below, we may even know less about the full extent of the financial system's vulnerability to climate risk than we did about its subprime mortgage exposures.

The vulnerability of climate science to sudden and abrupt movements, leading to cascading effects, is analogous to our understanding of financial panic manifestations. In a climate-driven financial crisis, however, climate forecasting's unpredictability is compounded by the unpredictable behavior of financial markets. This complicated lattice of risk would be difficult to contain if it were to become unstable.

Individual financing decisions by large financial companies exacerbate the uncertainty of climate risk. They involve the direction of significant amounts of capital, on the order of billions of dollars, to businesses that operate in some of the world's most essential and sensitive biomes. When compared to other financing activities, the amounts involved may appear negligible. The reality is that "biomes and earth system processes, previously conceptualized as 'sleeping giants' in the carbon cycle or as 'tipping elements' in the earth system, and 'planetaryscale tipping points"' have had a "disproportionate influence on climate stability [Carrington, 2018]."Recent research suggests that, as a result of climate change, various planetary "tipping points" may now be more likely than previously thought.

Just as with attempts to presage financial panics, there is a high degree of uncertainty in predictive climate modeling, including the likelihood and magnitude of catastrophic events. If anything, climate models are more likely to underestimate the amount of climate change that we will experience over the long term, especially when attempting to predict extreme events based upon past trends.

V. Climate risk is both highly concentrated and significant and widespread.

Climate risk is highly concentrated in the largest U.S. financial institutions, which are major financiers of the industries driving climate change through lending, underwriting, investing, or combining these activities.

From 2016-2018, six of the eight largest U.S. bank holding companies loaned, underwrote, or otherwise financed over $\$ 700$ billion to fossil fuel companies, accounting for 37 percent of global fossil-fuel financing since the Paris Agreement was adopted. If the six largest bank holding companies' aggregate fossil fuel assets were themselves a standalone institution, they would be the seventh-largest bank holding company in the nation and would exceed the banking agencies' consensus asset threshold for a systemically important bank holding company.

As of 2016, large insurers reported $\$ 528$ billion in fossil fuel-related investments. These investments would, on a standalone basis, be the second-largest U.S. life insurer by assets. They are roughly equal to the amount of total consolidated assets held by the global insurance company AIG when FSOC designated it as a non-bank systemically important financial institution (SIFI).

One report estimates the "Big Three" asset managers hold at least $\$ 287$ billion in fossil fuel investments. Black Rock has the most substantial holdings of thermal coal, the highest density of coal holdings, and nearly $\$ 61$ billion in equity in four of the largest global oil companies, while Vanguard and State Street are in the top five for thermal coal intensity. 
The size of these financial exposures means that the largest financial institutions are vulnerable to potential climate-related losses in some sectors of the economy that could reach hundreds of billions of dollars per year. For example, the estimates of potential transition risks for capital markets vary, but they are projected to be quite large across individual sectors. The financial industry's potential exposures to combined physical and transition risk losses are estimated to be around $\$ 692$ billion. Projecting out to 2100 , the costs to the financial system could reach an estimated $\$ 69$ trillion by remaining on a $2^{\circ} \mathrm{C}$ increase pathway (Carbon Disclosure Project, 2018).

The size of the potential losses caused by climate change far exceeds other potential risks that financial regulators view as worthy of heightened scrutiny based on the threats they pose to financial stability (FSOC, 2018). For a sense of the relative size of climate financial risk, consider that the assets exposed to potential losses exceed the entire subprime mortgage market before the global financial crisis. In some scenarios, the global economic losses caused by climate change could reach $\$ 23$ trillion, three or four times the scale of the 2008 crisis (Schroders, 2018).

In addition to the concentration of climate risks, the reach of climate change is global, with additional systemic implications. Climate events touch almost all geographic regions: snow and ice in the Northeast; tornadoes in the Midwest; hurricanes in the South; droughts and wildfires in the West; and flooding in all of these regions.There are also international climate events, like earthquakes, tsunamis, and fires that can reverberate across the globe.

To appreciate the potential scope of climate risk, one can consider the concept of "telecoupling": "connections between geographically separate biomes and economic activities." There is mounting evidence that reaching climate tipping points in one region can increase the likelihood of achieving them in others. This is relevant to climate finance because financial investments and decisions have "cross-continental social and ecological effects." Indeed, the risks of climate "are not constrained by borders" and "affect economic systems which can transmit and amplify their effects across borders."

In financial theory, diversification across geographic regions, industries, and asset classes should offer stability when financial stress is localized. In reality, the global scale and scope of climate change could mean that it cannot be contained as a regional phenomenon, or diversified away. The combination of the comprehensive ranges of both the climate crisis and the largest financial institutions could create exposure and transmit contagion, giving rise to risks that are genuinely systematic and systemic.

C. Climate change produces negative externalities and creates moral hazard.

Negative externalities occur when "private parties enjoy the benefits of inefficient activity because they do not have to bear the full cost of these activities." Climate financial risk produces two sets of potent negative externalities. First, there is the carbon pollution that is pumped into the air-the "canonical example" of an externality in economics textbooks - as "polluting companies impose the costs of their activities on a usually unwitting public." Second, there are the financial costs created by climate change stressing individual companies, threatening failures, runs, panics, and the distress that spreads from the financial system to the broader economy, resulting in public rescues of the financial system.

By not adopting effective macro-prudential climate policies, financial regulators exacerbate the so-called "moral hazard" problem for the industries that drive climate change and the institutions that finance them. Allowing large, systemic financial companies to under-price the risk of their investments in climate change-causing industries provides non-transparent subsidies. Like all subsidies, this creates a financial incentive to stay on a particular policy path, perpetuating the ongoing direction of massive amounts of capital into climate change drivers like fossil fuel and deforestation businesses.

Again, this self-reinforcing dynamic exacerbates both the physical risks and the transition risks of a climatedriven financial crisis. A prospective climate-driven financial crisis could cause broader economic harm and possibly increase economic losses if the financial system's impairment coincides with climate-driven economic damage to certain exposed regions or industries. The financial sector's ability to support the broader economy in 
the event of climate-driven losses depends on the degree to which the climate crisis causes credit and other losses to the financial system itself.

One strain of post-crisis thinking argues that adequately addressing systemic risk requires public actors to have a broad range of tools and discretion to rescue the financial system and the specific actors within it. Steele (2020) has argued that post hoc measures are insufficient and that ex-ante measures are essential.

Steele (2020) argues further that "unless climate risks are properly priced through macro-prudential regulations, the culmination of these externalities will result in high public costs. Such costs may include but are not limited to, the costs of mitigating climate change-driven physical destruction in addition to relocating large populations away from climate-damaged regions. Other costs include economic rescues such as aid packages for areas that rely on fossil fuels or deforestation and buyouts of investors in industries that are currently being propped up by the carbon bubble. These and other public expenditures related to the physical and financial damage of a climate crisis are essentially bailouts that provide a windfall to shareholders and executives of the very companies currently driving the climate crisis at the expense of the public. This bailout will further exacerbate economic inequality, social unrest, and other economic, political, and social problems."

Even worse, however, climate bailout would do nothing to alleviate the underlying problem. Large-scale asset purchases, quantitative easing, and other extraordinary measures cannot remove carbon from the atmosphere once released.

\subsection{Conclusion}

This paper has attempted to provide a strong justification for incorporating climate change into academic finance and public policy in Africa. This is a crucial step to ensure that Africa does not lag in handling its development issues while at the same time embracing the sustainability framework. Africa's economy is as diverse as its constituent countries. Notwithstanding, decades of conflicts and wars in some countries within the African region have partly been linked to climate change. The southward migration of Fulani herders has also been linked to increasing deforestation, steady drops in water levels, desert encroachment in Guinea and Sudan-Sahel Savannah of West Africa, and the violent conflicts between herders and farmers. Africa's contribution to GHG and $\mathrm{CO} 2$ emissions may appear little relative to the rest of the industrialized world. Still, the emissions are growing while forests typically serve as useful carbon and GHG sinks are declining. The growth in GHG emissions by Egypt (112.4\%), Nigeria (84.4\%), Ghana (265.4\%), South Africa (43.8\%) and the entire SSA (35.5\%) over the 1990-2012 period is alarming when compared to regions that are experiencing climate-changerelated catastrophes caused by these emissions. As contained in table 3, between 1990 and 2016, the forest area in SSA has declined by 6.15 percent of the square kilometers that existed three decades ago. Recent evidence shows that excellent public and private governance helps contain negative externalities (Shive \& Foster, 2020).

Beyond the environmental impact, climate change can potentially destroy the six capitals of modern sustainable corporations and markets. Climate change is a source of financial risk because climate risk damages physical property, which can impart credit risks, amongst other effects. Climate change is also a threat to the financial system's stability through systemic risk transmitted through financial assets and institutions.

The primary drivers of carbon emission in SSA are electricity and heat, manufacturing and residential buildings, transportation, waste management, and other sectors. Innovative instruments in the form of debt and equity financing can be used to prosecute climate-compatible investments in urban and rural areas. Land-based funding is also an emerging source of finance for the private and public sectors. Due to a decline in yields of money market instruments, many institutional investors are awash with liquidity seeking for investment outlets. Since the claims on these institutions, cash flows are typically long-term so that infrastructure bonds could appeal to their investment objectives. The return on investment from infrastructural projects should go beyond traditional financial analysis and incorporate strategic environmental benefits for the present and the future. The BlackScholes options pricing model is amenable to this analytical procedure. 
Many public projects are now being executed in partnership with the private sector. Permanent budget deficits and rating downgrades would mean that developing African countries do not have limitless borrowing powers. Many social projects can be priced in ways to guarantee modest returns on investment to the sponsors or financiers.

Capital market efficiency is also vital to driving responsible investments and financing of corporations. The capital market must not starve climate-compatible investments such as clean energy technologies of needed funds based on traditional risk-return profiles. Also, lenders (including banks) in the financial markets should ensure that climate-related risks are incorporated into business transactions. Correctly, the potentially harmful effects of climate change on the climate-sensitive property should be factored into credit risks to facilitate efficient pricing.

The possibilities of integrating modern finance theories into the analysis and study of climate change also make this line of research a fertile ground for expanding disciplinary boundaries. Steefen (2018), Bernstein, et al. (2019), Engle, et al. (2020), Andersson, Bolton \& Samana (2016), Baldauf, et al. (2020), Giglio, et al. (2019), Krueger, Sautner, Starks (2020) are some of the excellent papers in this regard.

\section{References}

Adeniran, A. I. (2020) Climatic factors in Nigeria's farmer-herder conflict, Africa Portal Policy Briefing: Climate Change and Migration, May 2020.

Adeola, R. (2020) Climate change, internal displacement and the Kampala Convention, Africa Portal PolicyBriefing: Climate Change and Migration, May 2020.

Alok, S., Kumar, N. \& Wermers, R. (2020) Do fund managers misestimate climatic disaster risk? Review ofFinancial Studies, 33(3): 1146-1183

Andersson, M., Bolton, P. \& Samana, F. (2016) Hedging climate risk, Financial Analysts Journal, 72(3): 13-32

Anton, A. (2020) Taxing crude oil: A financing alternative to mitigate climate change, Energy Policy, $136: 111031$

Baldauf, M., Garlappi, L. \& Yannelis, C. (2020) Does climate change affect real estate prices? Only if you believe in it, Review of Financial Studies, 33(3): 1256-1295

Barnett, M., Brock, W. \& Hansen, L.P. (2020) Pricing uncertainty induced by climate change, Review of Financial Studies, 33(3): 1024-1066

Barro, R.J., (2015) Environmental protection, rare disasters and discount rates, Economica, 82: 1-23

Bento N., Gianfrate G., \& Groppo S.V. (2019), "Do crowdfunding returns reward risks? Evidence from cleantech projects," Technological Forecasting \& Social Change, 141: 107-116. DOI:10.1016/j.techfore.2018.07.007.

Bernstein, A., Gustafson, M. \& Lewis, R. (2019) Disaster on the horizon: The price effect of sea level rise, Journal of Financial Economics, 134(2): 253-272

Berrisford, S., Cirolia, L.R., \& Palmer, I. (2018) Land-based financing in sub-Saharan African cities,Environment and Urbanization, 30(1): 35-52

Black, F. (1972) Capital market equilibrium with restricted borrowing, Journal of Business, 45(3): 444-455

Black, F. \& Scholes, M. (1973) The pricing of options and corporate liabilities, Journal of Political Economy, 81: 637-654 
Brennan, M. \& Zhang, Y. (2020) Capital asset pricing with a stochastic horizon, Journal of Financial and Quantitative Analysis, 55(3): 783-827

Carney, M., (2015) Breaking the tragedy of the horizon-climate change and financial stability, Speech given at Lloyd's of London (29 September).

Carbon Disclosure Project (2018) Major risk or rosy opportunity: Are companies ready for climate change? https://www.cdp.net/en/reports/downloads/4588.

Choi, D., Gao, Z. \& Jiang, W. (2020) Attention to global warming, Review of Financial Studies, 33(3):11121145 .

Colenbrander, S., Lindfield, M., Lufkin, J., \& Quijano, N. (2018) Financing low-carbon, climate- resilient cities. Coalition for Urban Transitions, London and Washington D.C.

Das, P., Fuss, R., Hanle, B. \& Russ, I.N. (2020) The cross-over effect of irrational sentiments in housing,commercial property and stock markets, Journal of Banking and Finance, 114: 105799

Engle, R. F., Giglio, S., Kelly, B., Lee, H. \& Stroebel, J. (2020) Hedging climate change news, Review of Financial Studies, 33(3): 1184-1216

Fama, E.\& French, K. (2016) Dissecting anomalies with a five-factor model, Review of Financial Studies, 29(1):69-103

Fama, E. \& French, K. (2020) Comparing cross-section and time-series factor models, Review of Financial Studies, 33(5): 1879-1890

Floater, G, Dowling, D, Chan, D, Ulterino, M, Braunstein, J, McMinn, T \& Ahmad, E (2017) Global Review of Finance for Sustainable Urban Infrastructure. Coalition for Urban Transitions. London \& Washington, DC.: http://newclimateeconomy.report/workingpapers/workingpaper/global-review-of-financefor sustainable-urban-infrastructure/

FSOC (2018) Financial Stability Oversight Council Annual Report 2018.

Giglio, S., Maggiori, M., Stroebel, J. \& Weber, A. (2019) Climate change and long-run discount rates: Evidence from real estate, Working Paper.

Giglio, S. \& Xiu, D. (2019) Asset pricing with omitted factors, Chicago Booth Research Paper.

Gollier, C.\& Tirole, J. (2015) Negotiating effective institutions against climate change. Econ. Energy Environ. Policy4: 5-27.

Hong, H., Li, F. W. \& Xu, J. (2019) "Climate risks and market efficiency," Journal of Econometrics, 208: 265281.

Hong, H., Karolyi, G.A. \& Scheinkman, J. A. (2020) Climate finance, Review of Financial Studies, 33(3): 10111023

Lambert, M., Fays, B. \& Hubner, G. (2020) Factoring characteristics into returns: A clinical study on the SMB and HML portfolio construction methods, Journal of Business Finance, 114: 105811.

Mapitsa, C. B. (2020) Multi-local livelihoods, climate change and urban vulnerability, Africa Portal Policy Briefing: $\quad$ Climate Change and Migration, May 2020.

Markowitz, H. (1952) Portfolio selection, Journal of Finance, 7(1): 77-99 
Markowitz, H. (1959) Portfolio selection: Efficient diversification of investments, Cowles Foundation Monograph No.16, New York: John Wiley \& Sons Inc.

Merton, R. (1973) An intertemporal capital asset pricing model, Econometrica, 41:867-887

Miller, M.H. (1977), Debt and taxes, Journal of Finance, 32: 261-276.

Modigliani, F. \& Miller, M. H. (1958) The cost of capital, corporation finance and the theory of investment, American Economic Review, 48: 261-296

Modigliani, F. \& Miller, M. H. (1963) Corporate income taxes and the cost of capital: A correction, AmericanEconomic Review, 53: 433-443.

Murfin, J. \& Spiegel, M. (2020), Is the risk of sea level rise capitalized in residential real estate? Review of Financial Studies, 33(3):1217-1255.

Myers,S.C.(1977)The determinants of corporate borrowing, Journal of Financial Economics,5:147-175.

Nordhaus, W. (2015) Climate clubs: overcoming free-riding in international climate policy, American Economic Review 105, 1339-1370

Nordhaus, W. (2019) Climate change: The ultimate challenge for economists, American Economic Review, 109: $\quad 1991-2014$

Olutola, O. (2020) Addressing the climate-migration nexus in the UN-AU partnership, Africa Portal Policy Briefing: Climate Change and Migration, May 2020.

Owigo, J. \& Yusuf, O. (2020) Return and (re)integration in fragile contexts: The experience of Somali returnees, Africa Portal Policy Briefing: Climate Change and Migration, May 2020

Painter, M. (2020) An inconvenient cost: The effects of climate change on municipal bonds, Journal of Financial Economics, 135(2): 468-482.

Roll, R. (1984) Orange juice and weather, American Economic Review, 74(5): 861-880

Schroders (2018) "Climate dashboard points to $4^{\circ} \mathrm{C}$ rise despite healthy increase in carbon prices," Oct. 17 , 2018, https://www.schroders.com/en/south-africa-

insightsinst/markets/climate_dashboard_points_to_4_degree_rise_despite_healthy_increase_in_carbon_prices

Sharpe, W. F.(1964) Capital Asset Prices: A theory of market equilibrium under conditions of risk, Journal of Finance, 19: 425-442.

Shive, S. A. \& Foster, M. M. (2020) Corporate governance and pollution externalities of public and private firms, Review of Financial Studies, 33(3): 1296-1330

Steele, G. S. (2020) Confronting the 'Climate Lehman Moment': The case for macro-prudential climate regulation, Forthcoming Cornell Journal of Law and Public Policy

Steffen, B. (2018) The importance of project finance for renewable energy projects, Energy Economics, 69: 280294

Stewart, R. B., Kingsbury, B. \& Rudyk, B. (2009) Climate finance for limiting emissions and promoting Green development: Mechanisms, regulation and governance, in climate Finance: Regulatory and Funding Strategies for Climate Change and Global Development, Stewart, et al. (eds), New York UniversityPress. 
Stiglitz, J.E., Stern, N., Duan, M., Edenhofer, O., Giraud, G., Heal, G., Lèbre la Rovere, E., Morris, A., Moyer, E., Pangestu, M., Shukla, P.R., Sokona, Y.S., \& Winkler, H. (2017) Report of the High-Level Commission on Carbon Prices, Carbon Pricing Leadership Coalition. 